Journal of Law \& Social Studies (JLSS)

Volume 1, Issue 1, pp 39-44

www.advancelrf.org

\title{
EFFECTS OF FALSE NEWS ON DECISION MAKING, ACCORDING TO ISLAMIC OUTLOOK
}

\author{
Shama Razi \\ Assistant Professor, Department of Business Administration, \\ Lahore School of Economics, Lahore, Pakistan \\ shama@1ahoreschool.edu.pk \\ Hammna Jillani \\ Teaching Associate (Visiting Faculty), Department of Environmental Sciences \& Policy, \\ Lahore School of Economics, Lahore, Pakistan
}

\begin{abstract}
In Islam, there is strict prohibition of sneering at people, mocking and bad-mouthing. Islamic perspective shows spreading of such news which isn't verified and is solely on the basis of guess, suspicion and delusions is prohibited. Moreover, Muslims are forbidden of spreading rumors and false information/news without any verification. There are different models studied under the decision making such as a) rational model, b) the administrative model, and c) the Retrospective Decision-Making Model. Fabrication of false/wrong accusation about any person is another atrocious sin. Muslims rely on moral principles for their decision making process, any false/fake news not only harm their mutual relationships in the society also it will lead to misconceptions. The foremost theme is to keep Muslims away from any commotion which intentionally or unintentionally hurts any other person and he has to be in the pang of guilty afterwards. This study identifies the adverse impacts of spreading fake news and how it is prohibited from Islamic evidences. Moreover, a link between decision making and impact of news on it is developed based on the review of existing literature.
\end{abstract}

KEYWORDS: Islamic Decision Making, False News, Slandering, Defaming, News Authentication

\section{INTRODUCTION:}

Islam is a religion of harmony. Being magnanimous is one of the traits mentioned persistently in the holy book Quran which is the charter of human rights. Islam proscribes any act or saying, that directly or indirectly; hits the self-esteem of any human being. Out of the prohibited acts; one is spreading false/fake news i.e. rumors. As Holy Prophet (Pbuh) said: 'The whole of the Muslim is sacred, his blood, his property and his honor' (Muslim Book 31, No. 6219). Muslims are prohibited of using foul language, backbiting and slandering repeatedly in the light of Quran and Hadith.

The word 'NEWS' is derived from the four directions i.e. North, East, West and South. It depicts the happenings and situations that happened or are likely to happen around us. News is often said to be the report of a contemporary event, basically the information that was not known earlier. In contrast according to the term fake news is actually any information that is sometimes intentionally meant to be false or fake.

Spreading of fake news could be on the basis of misconception and suspicion sometimes. Often there are financial or personal motivations too. According to Islamic perspective, spreading of such news which isn't verified and is solely on the basis of guess, suspicion and delusion and Muslims are prohibited to spread such news deliberately. Allah Almighty in Quran says: "O you who believe! Avoid much suspicion. Indeed some suspicions are sins. And spy not [on others], neither backbite one another. Would one of you like to eat the flesh of his dead brother? By no means, [sincel you would hate it. And fear Allah. Indeed, Allah is the One Who forgives and accepts repentance, Most Merciful" (Surah Al-Hujarat, 49:12).

Backbiting is another way of creating upheaval among families and friends, and to create misunderstandings among people just for the sake of nothing. It means mentioning something bad about a person, in his absence. It leads to spreading rumors which may have detrimental impacts upon the happy lives of people. Tongue, which is a blessing as people are able to communicate through it, occasionally it becomes a source of ache for any other person. It is narrated from Abu Huraira that the Messenger of Allah (PBUH) said: 'Whoever believes in Allah and the Last Day, 
let him speak good or else keep silent' (Al-Bukhari No. 6018, Muslim No. 47). Fabrication of false/wrong accusation about any person is another atrocious sin. Once Holy Prophet (Pbuh) passed by two graves and said: 'The inhabitants of these graves are being punished for major sins; one of them used to engage in slandering others' (Al-Bukhari Vol.2 Pg. 259). Furthermore, the emphasis on good speech is given at another place where the prophet of (PBUH) said: 'Blessed is the man who speaks good and is triumphant; or keeps silent in the face of evil and is secure (Tabrasi, Mashkat al-Anwar, p. 175, $2^{\text {nd }}$ Edition).

In Arabic false/fake news is called أخبار كاذبة / أخبار مزيفة'. In Islam, there is strict prohibition of sneering at people, mocking and bad-mouthing. Moreover, Muslims are forbidden of spreading rumors and false information/news without any verification. The main themes of tongue's evils are \{La Yaskhar (Scoffing), La Tamizu (Insulting), La TanabazuBilAlqab (Calling others by offensive names), La YaghtabBa'dhukumBa'dha (Backbiting) $\}$ and it is argued that the surrounding environment is the one foremost factor that makes people to utter such words (Ibrahim et al, 2017).

\section{LITERATURE REVIEW:}

A process of making a final choice between a set of alternatives is called decision making process. There are different models studied under the "decision making" such as a) rational model, b) the administrative model, and c) the Retrospective Decision-Making Model. The opposite of intuitive decision making is rational decision making, which is when individuals use analysis, facts and a step-by-step process to come to a decision (Turpin \&Marais, 2004). Decision making process is no different in Islamic perspective as well but there is one factor which holds paramount position in individuals' decision making method which is to believe in one GOD and the concept of accountability. As it comes in Holy Quran:

\section{"Every community is called to account" (Surah Al-Jaathiya, 45:28).}

People belong to religion Islam whenever they make any decisions they keep in mind the theory of hereafter accountability. As a Muslim we can not only think of this world and worldly benefits in whatever we do, consumer, produce or distribute; Muslim individuals constantly think of hereafter benefits and worldly benefits and make their choices accordingly (Ibrahim, 2000). Holy Quran also speaks about that no decision or final conclusion should be made without proper homework or research about the alternatives. It is necessary to inquire about the news or set choices before one make a final decision or make an opinion about someone and it is described in verse 12 of Holy chapter 49. Failure to do so will lead to unwanted results. Human beings should consult other fellow beings before reaching to any conclusion. But sometimes this lack of proper inquiry and hasty nature of a man will lead to negative outcomes. As it has been mentioned in Holy Quran:

\section{"Man is very hasty." (Surah Bani Isra'il, 17:11).}

Decision-making is a significant trust from God, and Islam demands from those holding this trust to provoke truthfulness and justice along with a spirit of consensus-seeking among participants. False or fake news is said to be an oxymoron by (Tandoc et al., 2017), on the basis of the fact that news is usually real and genuine. Each and every news should be authenticated and confirmed first, before making any decision in the religion Islam. To avoid any misperception, investigation and checking the reliability of information is the first step in order to spread anything. In Quran, Allah SWT has explained certain noble principles to spend life for Muslim community which can ultimately make a society ideal. ALLAH explains in Quran:

\section{“True believers are those who turn away from ill speech”(Surah Mominoon, 23:3).}

Criticizing and defaming others is a colossal sin and it makes a person very small in character. The above mentioned holy verse (23:3) also pinpoints one of the attributes of a true Muslim that true believers do not waste their time in irrelevant and immaterial activities. They understand the importance of this life and want to maximize their eternal utility by not indulging into such things. The focal intention of this Surah is to guide the Muslims towards the right conduit through describing various etiquettes to spend a good life. It includes, following the commandments of Allah Almighty and Holy Prophet (Pbuh), respect of each other, brotherhood, to confirm and verify any news before taking any action, sincerity in faith (Iman), avoidance of things that can create fuss and disorder between communities and to sidestep prejudgment and evils of tongue (Shahed et al., 2015).

Moreover, according to (Taher, 2017) Surah Al-Hujarat depicts the way through which the conditions of conflicts, clashes and disputes can be dealt according to an Islamic approach, and to live a life in accordance with the Islamic 
ethical codes. To elude backbiting, defaming and mocking shows that a person is obeying Allah and is trying to keep the evil away from him. As commanded: "O you who believe! If an evil-doer comes to you with important news, verify it, lest you should harm people in ignorance [out of haste in belief and making decision], and afterwards you become regretful for what you have done"(Surah Al-Hujarat, 49:6), a Muslim shouldn't instantaneously act on any kind of news unless it is verified.

(Visougi et al., 2018) elaborate the idea that Falsehood diffused significantly farther, faster, deeper, and more broadly than the truth in all categories of information. The theme is to keep Muslims away from any commotion which intentionally or unintentionally hurts any other person and he has to be in the pang of guilty afterwards. Furthermore, slandering and defaming is not only unlikable in Islam but also in other religions. This causes problems at individual level as well as in society level. As social norm it is important to have good relations with other members of the society so that it will help you in establishing good decisions in life.

"You sit and speak against your brother; you slander your own mother's son", (Psalm 50:20)

\section{OBJECTIVES:}

Through this research article, we are trying to answer the following interrogations:

- What are the effects of false/unreal news on decision making process

- Role of false news in damaging the credibility of an individual

- How harmful the false news can be for small groups/individuals

\section{METHODOLOGY:}

The current study is a desk based and a secondary research. To better understand about the impact of false news researchers studied Quran, Sunnah, and published articles, magazines, websites in this field and few key findings are extracted. The study has been done in the light of the research aims and scope/ objectives.

\section{EFFECTS OF FALSE NEWS:}

False news has many undesirable and negative effects, when spread deliberately or not. Some of them are discussed below:

\section{1) ON DECISION MAKING}

(Fontaine, 2008) identifies a list of 'thinking-tools' that allows Muslims to make decisions that are both ethical and moral. Muslims rely on moral principles for their decision making process, any false / fake news not only harm their mutual relationships in the society also it will lead to misconceptions. In a study (Ahmad, 2006) featuring decision making in an organization reveals that due to spread of false news people will end up making wrong decisions which will affect their performance at work. False news not only has negative impact on day to day tasks but also have harmful repercussions on the growth of human mind.

Out of three major decision making models; rational decision making is based on intimate facts, administrative is based on the decision maker that what criteria he might set for a final verdict whereas the third type is retrospective decision making in which the decision maker attempt to trim down their choices to make any decision (Lau, 2013). But none of the model depicts the idea of listening to proof-less thing and reaching a final judgment. Moreover (Rabbi, 2009) states man's own enemy is his own tongue, words of the evil from tongue damages his/her own character, the victim of evil report is wounded mentally and the person who listens also becomes an accomplice to the act. Therefore, the speaker as well as the decision maker needs to take the factor of authenticity in account.

\section{2) ON THE CREDIBILITY OF INDIVIDUALS}

A person earns his respect through his actions and good conduct. Prophet, peace be upon him, states: "Deeds are evaluated based on the objectives (intentions) behind them." He further states that: "If a ruler seeks the truth and achieves it, he is rewarded twice; if not he is rewarded once" (Ibrahim, 2000).

A man's credibility or his integrity grows with his good behavior in the society. Spreading our false or fake news in friends and family will damage his credibility and question his integrity. For first time he may be gets successful in 
fooling others with the false news but people will learn lesson from it and they'll never trust him in future. As it is mention in the Holy Quran: "And they who are to their trusts and their promises attentive" (Surah Mominoon, 23:8). This is not a quality of a true believer to spread false news and provide harm to others even for fun sake. One has to be careful about his actions, words, and dealings. Once the credibility of a man is lost it will never come back unless and until he repents sincerely with pure heart. Interestingly credibility is also implicit in the common reference to "prophets without honor" deriving from the biblical quotation: "Jesus said to them, 'A prophet is not without honor, except in his own country, and among his own relatives, and in his own house, notably in their own country' (Mark 6:4).

It has been noticed during the research that decision making process in both (Islamic Approach and non-Islamic approach) require complete knowledge of the situation before one makes the decision. Man's credibility and honesty will be at danger if he becomes famous for spreading false news; this also is true for all religions. Every religion (Islam, Christianity, Judaism etc.) supports the idea of mutual help and promotes the good-will of each other. We can see from the below mention bible verse that even in Christianity, consulting with each other before concluding to any results is given importance. Also if some wicked person brings in the news one should contempt and rejects it. "Whoever isolates himself seeks his own desire; he breaks out against all sound judgment. A fool takes no pleasure in understanding, but only in expressing his opinion. When wickedness comes, contempt comes also, and with dishonor comes disgrace. The words of a man's mouth are deep waters; the fountain of wisdom is a bubbling brook. It is not good to be partial to the wicked or to deprive the righteous of justice" (Proverbs 18:1-24).

\section{3) ON SMALL GROUPS}

Spreading false news not only will effect at individual level but it also injures group dynamics and makes people corrupt. Holy Chapter 49 verse 6 speaks about the false news brought to Prophet Pbuh by Walid bin Uqba when he was sent to collect tax from Banu Mustaliq tribe and he came back with false news. "O you who believe! If an evildoer comes to you with important news, verify it, lest you should harm people in ignorance lout of haste in belief and making decision], and afterwards you become regretful for what you have done"(Surah Al-Hujarat, 49:6).

It becomes essential for a group leader to inquire about the news before taking any actions. The incident shows the importance of verification of news prior to take any action. Sometimes the harm done by tongue is more dangerous than the harm done with arms and weapons. Dialogue has more in solving issues between groups and bloc and if it is manipulated with wrong or false news then it will affect the future of the groups.

"And let us consider how we may spur one another on toward love and good deeds, not giving up meeting together, as some are in the habit of doing, but encouraging one another-and all the more as you see the Day approaching"(Hebrews 10:24-25).

Islam stresses on the fact that it is essential to consult others before making any final decision, say it for personal or professional decision, no single or personal judgment is encouraged in Islam. This is also indicates the concept of Ijtihad in Islamic economics. As Holy Quran mentions: "And those who have responded to their lord and established prayer and whose affair is (determined by) consultation among themselves, and from what we have provided them, they spend. "'(Surah Ashura, 42:38).

Henceforth, it is evident from Holy Scripture that in a Muslim society, Muslims are encourage to make decisions on the basis of collective consultation and reach at decisions which are beneficial for the society at large.

\section{FUTURE RESEACRH IDEA:}

The current study focuses on the effect of false on decision making and it does not cover the social media element in to the research. It suggested for future research if a thorough analysis would be done on what is the impact of false / fake messages displayed / posted on social media (like facebook, twitter, instagram etc) on Muslim youth then it would be interesting research. Another interesting aspect would be if a future study focuses on the fake news being broadcasted on Television which have always supported through some hidden or known political agenda.

\section{CONCLUSION:}

This study argues that from an Islamic perspective, false news can affect human beings belonging to all religions and culture. Man, being a social animal often gets tangled within the boundaries of what is he told and what he observes. 
Lies spread faster than the truth. There is worldwide concern over false news and the possibility that it can influence political, economic, and social well-being. Therefore, one should not accept everything blindly whatever is informed. Humans are blessed with the capability of thinking and this blessing should be used wholeheartedly. Moreover, the blessing of speaking should be used appropriately as an explicit stipulation is that one must not speak unless one's words are good and that the benefit in doing so is clear and preponderant. The vicious cycle of thinking and speaking should be kept in control so that neither it harms others not the person.

The article also builds a clear link between wise speech and its spreading. Whosoever speaks bad and spreads bad/fake or false news is doing a sin, which should be proximately avoided. Furthermore, false news breaks the trust and authenticity among people. It creates an unseen distance and hatred in heart which is not acceptable and tolerated among a Muslim community. Sometimes on the factors of jealousy and suspicion false news is communicated; but this should be evaded as previously mentioned, it's a sin. As ALLAH mentions in Quran:

"When you were propagating it with your tongues, and uttering with your mouths that whereof you had no knowledge, you counted it a little thing, while with Allah it was very great"(Surah An-Nur, 24:15).

The consequences are ruinous i.e. credibility of the person is damaged in front of others, creation of distance between people and sometimes a wrong decision could lead to have disastrous effect upon the lives of innocent people. By taking in account all these arguments, news authentication is a must factor. Moreover, fake news should be promptly refuted and negated whether in any religion. After the deep analysis of Quran and other religions Holy Scriptures it is established that fake news corrupt and harms the whole system.

\section{REFERENCES:}

Abul Kalam Muhammad Shahed, Noor Muhammad Osmani\& Muhammad Abu Bakr Siddique (2015). Surah AlHujurat: A Charter of Ideal Social Life. Bangladesh Journal of Islamic Thought, 11(16).

Ahmad, K. (2006). “Management from an Islamic perspective.” Kuala Lumpur: International Islamic University Malaysia.

Al-Bukhari Vol.2 Pg. 259

Al-Bukhari Number 6018 and Muslim Number 47

Ibrahim, M. A., Yusoff, Z. H., Anas, M. M., Amin, M. Z., \&Safiai, F. W. (2017). The Importance of Restraining Our Tongue According To The Quran: An Implementation Among The Students. IJASOS- International E-journal of Advances in Social Sciences, 167-167. doi:10.18769/ijasos.309672

Ibrahim. S, (2000). Decision under uncertainty, An Islamic perspective. Al-Rajhi Banking and Investment Corp, Riyah Saudi Arabia.

Lau, R. R. (2003). Models of decision-making. In D. O. Sears, L. Huddy, \& R. Jervis (Eds.), Oxford handbook of political psychology (pp. 19-59). New York, NY, US: Oxford University Press.

Mehri Taher (2017). Contextual Analysis of the Verses 11 tol 8 of Surah al-Hujurat And its Comparative Review. Burhan Journal of Qur'anic Studies www.academicpress.org ISSN 2383-2932 (Online) Vol 02, No.01

Muslim Book 31, Number 6219

Fontaine (2008). Islamic moral responsibility in decision making. Journal of Economics and Management 16, Vol. 2.

Rabbi Sholomo Ben Levy (2009). The Evil Tongue. www.JSafe.org

S.M. Turpin and M.A. Marais (2004). Decision-Making: Theory and Practice. Vol 20 no. 2 //dx.doi.org/10.5784/20$2-12$

Tabrasi, Mashkat al-Anwar, p. 175, 2nd Edition

Tandoc, E. C., Lim, Z. W., \& Ling, R. (2017). Defining “Fake News". Digital Journalism, 6(2), 137-153. doi:10.1080/21670811.2017.1360143

The Bible, Chapter 50 Psalm, Verse 20 
The Bible, Chapter 6 Mark, Verse 4

The Bible, Chapter 18 Proverbs Verse 1-24

The Bible, Chapter 10 Hebrews, Verse 24-25

The Holy Quran, Chapter 17 Surah Bani Isra'il, Verse 11

The Holy Quran, Chapter 23 Surah Al-Mominoon, Verse 3

The Holy Quran, Chapter 23 Surah Al-Mominoon, Verse 8

The Holy Quran, Chapter 24 Surah An-Nur, Verse 15

The Holy Quran, Chapter 42 Surah Ashura, Verse 38

The Holy Quran, Chapter 45 Surah Al-Jaathiya, Verse 28

The Holy Quran, Chapter 49 Surah Al-Hujarat, Verse 6

The Holy Quran, Chapter 49 Surah Al-Hujarat, Verse 12

Vosoughi et al., (2018). The spread of true and false news online. Science 359, 1146-1151. 